\title{
DRUG ALLERGIES DUE TO IgE SENSITIZATION TO $\alpha$-GAL
}

\author{
FLORIN-DAN POPESCU ${ }^{1}$, OANA MARIANA CRISTEA ${ }^{2 *}$, FLORIANA-ELVIRA IONICA $^{3}$, \\ MARIANA VIERU ${ }^{1}$
}

Department of Allergology, "Carol Davila” University of Medicine and Pharmacy, Bucharest, Romania

${ }^{2}$ Department of Microbiology, University of Medicine and Pharmacy of Craiova, Craiova, Romania

${ }^{3}$ Faculty of Pharmacy, University of Medicine and Pharmacy of Craiova, Craiova, Romania

*corresponding author: oanamarianacristea@gmail.com

Manuscript received: June 2018

\begin{abstract}
Serum specific IgE antibodies for non-primate mammalian carbohydrate galactose- $\alpha-1,3$-galactose ( $\alpha$-Gal) are associated to $\alpha$-Gal syndrome: delayed allergy to red meat manifested as anaphylaxis, angioedema or urticaria after ingestion of beef, pig or lamb meat, immediate-onset anaphylaxis at first parenteral exposure to drugs significantly containing $\alpha$-Gal. IgE-mediated drug allergy in the $\alpha$-Gal syndrome was reported for some therapeutic monoclonal antibodies, such as cetuximab, snake antivenom, and varicella-zoster vaccine, but there are risks also for colloid plasma volume substitutes, vaccines containing gelatine of porcine/bovine animal origin as an excipient, and drugs with porcine pancreatin or bovine-origin magnesium stearate.
\end{abstract}

\section{Rezumat}

Anticorpii IgE specifici serici pentru carbohidratul galactoză- $\alpha-1,3$-galactoză ( $\alpha$-Gal) al mamiferelor non-primate sunt asociați cu sindromul $\alpha$-Gal: alergie tardivă la carnea roșie manifestată ca anafilaxie, angioedem sau urticarie după ingerarea de carne de vită, porc sau miel, anafilaxie imediată la prima expunere parenterală la medicamente care conţin în mod semnificativ $\alpha$-Gal. Alergia mediată de $\operatorname{IgE}$ la medicamente în sindromul $\alpha$-Gal a fost raportată pentru anumiţi anticorpi monoclonali terapeutici, cum ar fi cetuximabul, antiveninul de şarpe şi vaccinul varicelo-zosterian, dar există riscuri şi pentru substituenții plasmatici coloidali de volum, vaccinuri care conțin gelatină de origine animală porcină/bovină ca excipient și medicamente cu pancreatină porcină sau stearat de magneziu de origine bovină.

Keywords: $\alpha$-Gal syndrome, allergy, anaphylaxis, drug allergy

\section{Introduction}

The galactose- $\alpha$-1,3-galactose ( $\alpha$-Gal) represents a particular disaccharide antigen present in the chemical structure of glycolipids and glycoproteins of the nonprimate mammals (more than $10^{6}$ epitopes per cell). Humans and superior primates have functionally lost in their evolution the $\alpha 1,3-$ galactosyltransferase gene. The $\alpha$-Gal is not expressed in the human tissues, therefore this epitope is highly immunogenic. In all nonimmunocompromised human subjects, IgG antibodies against $\alpha$-Gal are present, their continuous production being a response to intestinal bacteria expressing $\alpha$-Gal [6, 18, 23, 24, 46, 47, 52, 57]. The $\alpha$-Gal molecule is present in considerable amounts in red meat, such as pork, beef, mutton, horse and offal (e.g. kidney, liver), but ingestion of such animal food does not induce sensitization against $\alpha$-Gal. IgE-mediated sensitization to the $\alpha$ Gal epitope in humans was quite recently proved to be a consequence of hard tick bites. Patients with a personal history of multiple tick bites may experience IgE-mediated sensitization to $\alpha$-Gal [9, $12,13,18,20,51,52]$. IgE reactivity to this epitope is common in endemic tick areas. In the case of discrete levels of serum specific IgE against $\alpha$-Gal, sensitized subjects appear not to develop meat allergy [50-52, 57]. There is a close relationship between the tick bites personal history and the serum levels of specific IgE against $\alpha$-Gal [56]. This epitope is present in some drugs of animal origin, excipients or ingredients, and therapeutic chimeric monoclonal antibodies.

The $\alpha$-Gal epitope represents the mammalian crossreactive carbohydrate determinant (CCD) with clinical significant involvement in the $\alpha$-Gal syndrome. Other CCDs from glycosylated plant proteins and venoms of Hymenoptera insects are instead a usual cause of clinically irrelevant in vitro IgE testing positive results [1, 22, 59]. Although patients allergic to red meat with specific IgE response against $\alpha$-Gal are considered not to have $\mathrm{IgE}$ antibody responses to CCDs from plants [2], a case of delayed food allergy to various red meats was reported in a Romanian adult patient with great tick bites and other arthropods exposure, associated with serum IgE against plant-derived CCD $[39,54]$. 


\section{The $\alpha$-Gal syndrome}

Serum specific $\operatorname{IgE}$ antibodies to the nonprimate mammalian epitope $\alpha$-Gal are associated with the $\alpha$-Gal syndrome: delayed allergy to the red meat manifested as late-onset anaphylaxis, urticaria or angioedema after ingestion of pig, beef or lamb meat, anaphylaxis with immediate onset at initial parenteral exposure to drugs significantly containing $\alpha$-Gal, such as cetuximab $[12,13,17,55]$.

Mechanisms for inducing IgE-mediated sensitization to $\alpha$-Gal are complex. Ticks with hard shells belonging to the Ixodidae family, including Ixodes ricinus in Europe and Amblyomma americanum in North America, are important arthropod agents involved in human IgE-mediated sensitization to $\alpha$ Gal [57]. Tick bites represent the major cause of the specific IgE responses to this epitope, saliva of Ixodidae ticks being contaminated with nonprimate mammalian blood group $\alpha$-Gal carbohydrate [12, $13,57]$, and $\alpha$-Gal being detected in the Ixodes ricinus tick gastrointestinal tract $[20,21]$. Moreover, $\alpha-\mathrm{Gal}$ is present at the site of the tick bite. Local immunomodulator factors, such as phospholipase A2, prostaglandin E2, and lipocalins, promote $\mathrm{Th}_{2}$ cell responses and IgE isotype switching [7]. The $\alpha$-Gal chemical structure is similar to the human blood group B antigen, therefore B-positive blood group is associated with a lower production of specific IgE against it $[3,21]$. In subjects presenting $\operatorname{IgE}$ sensitization to the epitope $\alpha$-Gal, clinical allergic reactions having immediate onset may be induced by first parenteral exposure to drugs containing this epitope. After ingesting oral drugs of bovine/porcine origin or red meat, the allergic reactions have a late onset, in 3-6 hours. Allergenic $\alpha-\mathrm{Gal}$ is stable to heat and pepsinolysis and has a prolonged chylomicron transport from the intestine through mesenteric lymph nodes in circulation $[3,4,12,13,57]$.

\section{IgE-mediated drug allergy in $\alpha$-Gal syndrome}

Although this special type of drug hypersensitivity in patients presenting IgE-mediated sensitization to $\alpha$-Gal oligosaccharide was reported for some therapeutic monoclonal antibodies, antivenoms, and vaccines (Table I), there are also potential risks for colloidal plasma volume substitutes and other drugs containing gelatin of porcine/bovine origin, or drugs with porcine pancreatin. Moreover, because most such adverse reaction reports are recent, to our knowledge there is no published updated comprehensive review from a pharmaceutical and pharmacological perspective, and allergy information and education of physicians and pharmacists regarding this drug allergy are crucial.

Table I

Drug allergy cases reported in patients with $\operatorname{IgE}$ sensitization to $\alpha$-Gal

\begin{tabular}{|c|c|c|c|c|}
\hline Therapeutic class & Drug & $\begin{array}{c}\text { Hypersensitivity } \\
\text { reactions }\end{array}$ & $\begin{array}{c}\text { Publications } \\
\text { year(s) }\end{array}$ & References \\
\hline $\begin{array}{l}\text { Chimeric anti-EGFR } \\
\text { monoclonal antibody }\end{array}$ & cetuximab & $\begin{array}{l}\text { severe, even fatal, } \\
\text { anaphylaxis, at first } \\
\text { infusion, } \\
\text { series of cases }\end{array}$ & $2007-2017$ & $\begin{array}{l}{[11,25,37,} \\
38,55]\end{array}$ \\
\hline $\begin{array}{l}\text { Chimeric anti-TNF } \alpha \\
\text { monoclonal antibody }\end{array}$ & infliximab & $\begin{array}{c}\text { anaphylaxis, at first } \\
\text { dose, } \\
\text { case report }\end{array}$ & 2017 & {$[10]$} \\
\hline Snake antivenom & $\begin{array}{l}\text { crotalid polyvalent immune } \\
\text { Fab ovine }\end{array}$ & $\begin{array}{l}\text { generalized urticaria, } \\
\text { case report }\end{array}$ & 2017 & {$[42]$} \\
\hline $\begin{array}{l}\text { Colloidal plasma volume } \\
\text { substitutes }\end{array}$ & modified fluid gelatin & $\begin{array}{c}\text { intraoperative } \\
\text { anaphylaxis, } \\
\text { case reports }\end{array}$ & $2012-2014$ & {$[35,41,43]$} \\
\hline \multirow{3}{*}{$\begin{array}{l}\text { Vaccines and other drugs } \\
\text { containing gelatin and/or other } \\
\text { proteins of porcine/bovine } \\
\text { origin }\end{array}$} & $\begin{array}{c}\text { herpes zoster vaccine; } \\
\text { MMR, varicella, DTaP/IPV } \\
\text { vaccination }\end{array}$ & $\begin{array}{c}\text { anaphylaxis, } \\
\text { case reports (adult, } \\
\text { child) }\end{array}$ & $2017-2018$ & {$[47,48]$} \\
\hline & $\begin{array}{l}\text { oral drug formulations with } \\
\text { magnesium stearate of } \\
\text { bovine origin as an inactive } \\
\text { ingredient }\end{array}$ & $\begin{array}{l}\text { systemic allergic } \\
\text { reactions, case report }\end{array}$ & 2015 & {$[34]$} \\
\hline & $\begin{array}{l}\text { vaginal capsules with } \\
\text { porcine gelatin cover }\end{array}$ & $\begin{array}{l}\text { anaphylaxis, case } \\
\text { report }\end{array}$ & 2016 & {$[53]$} \\
\hline
\end{tabular}

\section{IgE-mediated allergy to therapeutic monoclonal antibodies in $\alpha$-Gal syndrome}

Hypersensitivity to some monoclonal antibodies has been associated with the existence of specific
IgE antibodies against $\alpha$-Gal epitopes present on the molecules.

Cetuximab is a recombinant human/mouse chimeric monoclonal antibody which binds with specificity to the extracellular region of the human 
FARMACIA, 2019, Vol. 67, 1

epidermal growth factor receptor (EGFR), authorized as intravenous infusion for the therapy of EGFR-expressing, RAS wild-type metastatic colorectal cancer and head and neck squamous cell carcinoma. Cetuximab is obtained in mammalian murine myeloma cell culture. Cetuximab contains Fv domains of a murine anti-EGFR antibody and human $\operatorname{IgG}_{1}$ heavy and kappa light chain constant regions. The Fab region of the heavy chain is glycosylated at Asn 88 position with carbohydrates, including $\alpha$-Gal. The presence of this epitope on both Fab segments allows cross-linking of the $\operatorname{IgE}$ molecules on the mast cells, with degranulation and thus releasing of hypersensitivity mediators involved in the pathogenesis of anaphylaxis [11, 28, $40,45,60]$.

Initial evaluations of severe hypersensitivity allergic reactions to this therapeutic monoclonal antibody considered that these occur in about $3 \%$ of subjects, but studies in particular regions in the United States (Tennessee and North Carolina) revealed that $22 \%$ of patients treated with such chimeric monoclonal antibodies have severe hypersensitivity reactions. In most subjects, serum $\mathrm{IgE}$ antibodies to cetuximab were detectable before treatment, and these were specific for the $\alpha$-Gal epitope [37]. It is considered nowadays that severe infusion-related adverse reactions to cetuximab, including anaphylaxis, may commonly appear, in several cases with fatalities. A severe reaction related to the infusion of this drug requires urgent and permanent cessation of the treatment, and necessitates emergency appropriate therapy. Anaphylactic reactions may occur quickly within minutes of the initial infusion, attributable to preformed specific IgE antibodies reacting with the $\alpha$-Gal present in cetuximab. Such reactions can happen regardless of the use of premedication. The risk for anaphylaxis is increased in subjects with a personal history of hypersensitivity to the red meat or tick bites or positive in vitro testing results for specific IgE to cetuximab $\alpha$-Gal $[11,25,37,60]$.

Panitumumab, which is a recombinant completely human $\mathrm{IgG}_{2}$ anti-EGFR monoclonal antibody, without $\alpha$-Gal epitope on its Fab portion, is indicated as intravenous infusion for the therapy of adults with the RAS wild type metastatic colorectal cancer. This drug was tolerated as parenteral monotherapy, in a case series small trial, in subjects with previous severe infusion-related adverse reactions to cetuximab [29]. Tomuzotuximab is a glycoengineered second generation antibody of cetuximab, with the elimination of the previously mentioned $\alpha$-Gal molecule, thus having improved tolerability [15].

Chimeric (human/murine) monoclonal $\mathrm{IgG}_{1}$ antibodies with $\alpha$-Gal epitopes on their intact $\mathrm{Fc}$ domains, such as the anti-CD25 basiliximab and anti-respiratory syncytial virus fusion protein palivizumab, does not bind specific $\operatorname{IgE}$ to the $\alpha$ Gal molecule, probably because of the steric interference of a polypeptidic structure around the disaccharide [28, 44].

Other therapeutic monoclonal antibodies derived from cell lines that glycosylate with galactose- $\alpha$ 1,3-galactose, besides cetuximab, are anti- $\alpha 4$ integrin natalizumab and anti-TNF $\alpha$ infliximab. Recently, a first dose IgE-mediated anaphylaxis to infliximab due to $\alpha$-Gal sensitization was reported in a Crohn's disease patient with allergy to mammalian meat [10]. To avoid recurrence of allergic symptoms with subsequent treatment, vedolizumab, a humanized therapeutic monoclonal antibody binding the $\alpha_{4} \beta_{7}$ integrin, blocking the interaction of this heterodimeric molecule with MAdCAM-1, may be an option, being a non-glycosylated monoclonal antibody [10].

\section{Risk of IgE-mediated allergy to antivenoms in $\alpha$ - Gal syndrome}

North American crotalid snake polyvalent immune Fab ovine antivenom was reported to induce generalized urticaria during intravenous infusion in a patient with a history of tick exposures, bitten by the Agkistrodon contortrix snake [42].

The $\alpha$-Gal disaccharide may also be involved in IgE-mediated adverse reactions to equine antivenoms, being detected by immunoblot technique in viper (e.g. Malayan Pit Viper Antivenom), cobra (e.g. Indian Snake Venom Antiserum) and scorpion (e.g. Brazil Soro Antiscorpionico) [16].

\section{Risk of IgE-mediated allergy to plasma volume substitutes in $\alpha$-Gal syndrome}

Intraoperative anaphylaxis to bovine-derived gelatine colloid plasma volume substitutes was reported, including in $\alpha$-Gal allergy [35, 41, 43]. The colloidal solution for infusion with succinylated gelatine contains about $0.52 \mu \mathrm{g} \alpha$-Gal per gram, similar to the colloidal intravenous infusion solution with polygeline or degraded gelatine polypeptides cross-linked via urea bridges (about $0.44 \mu \mathrm{g} \alpha$-Gal per gram), both containing about 4000 times less $\alpha$ Gal compared to cetuximab $(10.2 \mu \mathrm{g} \alpha$-Gal per 5 $\mathrm{mg}$ in $1 \mathrm{~mL}$ solution for infusion) [35].

\section{Risk of IgE-mediated allergy to gelatine- containing vaccines in $\alpha$-Gal syndrome}

Vaccines that contain gelatine or bovine calf-serum may induce anaphylaxis in patients sensitized to $\alpha$ Gal, although not all subjects have adverse reactions. There is a report of immediate anaphylaxis to injected herpes zoster vaccine with Oka varicellazoster virus and hydrolysed gelatine as an 
FARMACIA, 2019, Vol. 67, 1

ingredient, in an adult with $\alpha$-Gal IgE sensitization and recurrent anaphylaxis [48]. The content of hydrolysed gelatine as vaccine stabilizer per dose was reported as $15580 \mathrm{mg}$ porcine gelatine in 0.65 $\mathrm{mL}$ of a varicella-zoster vaccine, $14500 \mathrm{mg}$ bovine gelatine in $0.5 \mathrm{~mL}$ of a measles, mumps, rubella vaccine, and $7500 \mathrm{mg}$ porcine gelatine in $0.5 \mathrm{~mL}$ of a yellow fever vaccine $[36,48]$.

Another recent report was published regarding a paediatric subject with a pre-existing $\alpha$-Gal IgEmediated hypersensitivity, who presented anaphylaxis rapidly after administration of the usual 5-year vaccination with measles, mumps, and rubella (MMR), varicella, and diphtheria, tetanus, and acellular pertussis, and inactivated polio vaccine (DTaP/IPV). Both varicella and MMR vaccines contain significant quantities of gelatine (per dose: $12,500 \mathrm{mg}$ in $0.5 \mathrm{~mL}$ and $14,500 \mathrm{mg}$ in $0.5 \mathrm{~mL}$, respectively). Moreover, DTaP/IPV, MMR, and varicella vaccines also include bovine serum ingredient in unreported amounts [47].

\section{Risk of allergy to other drugs with ingredients of porcine/bovine origin}

Although $\alpha$-Gal is not present on heparin molecules, being derived from porcine intestinal mucosa there is a potential of contamination with this epitope in the manufacturing process, with a theoretical risk in patients with $\alpha$-Gal allergy [27]. The $\alpha$-Gal carrying proteins were instead recently detected by immunoblot technique in porcinederived oral medications, such as gastro-resistant capsules with porcine pancreatin (amylase, lipase, protease) microspheres, used in the therapy of exocrine pancreatic insufficiency in chronic pancreatitis, pancreatic cancer, cystic fibrosis or post-pancreatectomy, and gastro-resistant coated tablets with porcine pepsin as supportive medication for gastrointestinal malfunction [49].

Vaginal capsules may also represent a hidden source of exposure to the $\alpha$-Gal epitope, a case of anaphylaxis was reported in a female patient diagnosed with $\alpha$-Gal allergy, after application of an intravaginal capsule with gelatine cover with collagen of porcine origin [53].

A case report of $\alpha$-Gal allergy associated with an allergic reaction to drugs containing magnesium stearate probably of bovine origin was also published, underlying that medical practitioners and pharmacists should be aware of potential crossreactivity between $\alpha$-Gal and drugs with meat byproducts, considering that inappropriate avoidance is correlated with a risk of anaphylaxis [34]. Bovine-based magnesium stearate may be used as a lubricant excipient to facilitate tablets ejection [19].

\section{Allergy diagnosis for drug allergy in $\alpha$-Gal} syndrome

Allergological diagnosis approach includes, besides a detailed patient history, in vivo and in vitro allergy testing. In vivo diagnosis in $\alpha$-Gal allergy may include allergy skin testing and challenge tests with meat or meat extracts, but not all are usually recommended for ethical reasons, related to standardization or biological safety. Skin prick tests with selected meat extracts may be equivocal or negative. Allergy skin testing performed with cetuximab is more sensitive and it is performed as skin prick test with cetuximab solution for infusion $5 \mathrm{mg} / \mathrm{mL}$, followed by an intradermic test with cetuximab solution for infusion $0.05 \mathrm{mg} / \mathrm{mL}$ (1: 100 dilution) [33].

Serum specific IgE to $\alpha$-Gal in vitro detection using immunoenzymatic ELISA as a commercially sensitive test must take into consideration that it can also be positive in patients with parasitic infections and in a tick-endemic population. Serum specific IgE to bovine thyroglobulin may be determined by singleplex fluorescence immuneenzymatic assay (FEIA) with activated cellulose solid phase. Patients with $\alpha$-Gal syndrome have elevated levels of serum specific IgE against bovine thyroglobulin, a protein containing $5.6 \mu \mathrm{g} \alpha$-Gal per gram. Serum specific IgE to cetuximab by ELISA or FEIA immunoenzymatic methods, using biotinylated anti-IgE antibodies and streptavidinalkaline phosphatase conjugate is also useful, because patients with $\alpha$-Gal syndrome have high concentrations of serum specific IgE to cetuximab, a monoclonal antibody containing $2.04 \mu \mathrm{g} \alpha$-Gal per mg [30, 31].

The basophil activation test (BAT) with cetuximab $(\mathrm{CD} 203 \mathrm{c})$ or porcine pancreatin (CD63) is an alternative in vitro evaluation of $\alpha$-Gal sensitization $[5,3133,49]$. The assessment of $\mathrm{CD}^{+} 3^{+}$basophils induced by $\alpha$-Gal and after stimulation with antiFecRI may be used to distinguish asymptomatic sensitization from $\alpha$-Gal syndrome [32].

The most used diagnostic methods in the $\alpha$-Gal syndrome are the intradermal test for cetuximab allergy and the detection of specific $\operatorname{IgE}$ against $\alpha$ Gal for the allergy to red meat [55]. Implementing BAT beyond research poses some questions about reproducibility [58].

\section{Conclusions}

It is noteworthy to mention that the lack of universal awareness of drug allergy due to $\operatorname{IgE}$ sensitization to $\alpha$-Gal may lead to misdiagnosis or delayed diagnosis, and puts allergic patients at risk for anaphylaxis $[8,14,26]$. Because manufacturers do not commonly assess the $\alpha$-Gal content in pharmaceutical products, it is important for 
FARMACIA, 2019, Vol. 67, 1

allergists and pharmacists to be aware of this problem [34, 51] and to identify the risk medications, such as the drugs with mammalian sources having the potential for contamination with $\alpha$-Gal, and the pharmaceutical products with ingredients containing $\alpha$-Gal epitopes, that may provoke a potentially severe allergic reaction in patients with $\alpha$-Gal IgE sensitization.

\section{References}

1. Altmann F, Coping with cross-reactive carbohydrate determinants in allergy diagnosis. Allergo J Int., 2016; 25(4): 98-105.

2. Apostolovic D, Krstic M, Mihailovic J, Starkhammar M, Cirkovic Velickovic T, Hamsten C, van Hage M, Peptidomics of an in vitro digested $\alpha$-Gal carrying protein revealed IgE-reactive peptides. Sci Rep., 2017; 7(1): 1-10.

3. Apostolovic D, Tran TA, Starkhammar M, SánchezVidaurre S, Hamsten C, Van Hage M, The red meat allergy syndrome in Sweden. Allergo J Int., 2016; 25(2): 49-54.

4. Apostolovic D, Tran TA, Sánchez-Vidaurre S, Cirkovic Velickovic T, Starkhammar M, Hamsten C, van Hage $\mathrm{M}$, Red meat allergic patients have a selective $\operatorname{IgE}$ response to the $\alpha$-Gal glycan. Allergy, 2015; 70(11): 1497-1500.

5. Arkestål K, Sibanda E, Thors C, Troye-Blomberg M, Mduluza T, Valenta R, Grönlund H, van Hage M, Impaired allergy diagnostics among parasite-infected patients caused by IgE antibodies to the carbohydrate epitope galactose- $\alpha$ 1,3-galactose. J Allergy Clin Immunol., 2011; 127(4): 1024-1028.

6. Cabezas-Cruz A, de la Fuente J, Immunity to $\alpha$-Gal: The opportunity for malaria and tuberculosis control. Front Immunol., 2017; 8: 1-6.

7. Cabezas-Cruz A, Mateos-Hernández L, Chmelar̆ JC, Villar M, de la Fuente J, Salivary prostaglandin E2: role in tick-induced allergy to red meat. Trends Parasitol., 2017; 33(7): 495-498.

8. Carter MC, Ruiz-Esteves KN, Workman L, Lieberman P, Platts-Mills TAE, Metcalfe DD, Identification of alpha-gal sensitivity in patients with a diagnosis of idiopathic anaphylaxis. Allergy, 2018; 73(5): 1131-1134.

9. Chinuki $\mathrm{Y}$, Ishiwata $\mathrm{K}$, Yamaji $\mathrm{K}$, Takahashi $\mathrm{H}$, Morita E, Haemaphysalis longicornis tick bites are a possible cause of red meat allergy in Japan. Allergy, 2016; 71(3): 421-425.

10. Chitnavis M, Stein DJ, Commins S, Schuyler AJ, Behm B, First-dose anaphylaxis to infliximab: a case of mammalian meat allergy. J Allergy Clin Immunol Pract., 2017; 5(5): 1425-1426.

11. Chung CH, Mirakhur B, Chan E, Le QT, Berlin J, Morse M, Murphy BA, Satinover SM, Hosen J, Mauro D, Slebos RJ, Zhou Q, Gold D, Hatley T, Hicklin DJ, Platts-Mills TA, Cetuximab-induced anaphylaxis and IgE specific for galactose-alpha-1,3galactose. N Engl J Med., 2008; 358(11): 1109-1117.

12. Commins SP, Platts-Mills TA, Tick bites and red meat allergy. Curr Opin Allergy Clin Immunol., 2013; 13(4): 354-359.
13. Commins SP, Platts-Mills TAE, Delayed anaphylaxis to red meat in patients with $\mathrm{IgE}$ specific for galactose alpha-1,3-galactose (alpha-gal). Curr Allergy Asthma Rep., 2013; 13(1): $72-77$.

14. Dupont B, Mariotte D, Dugué AE, Clarisse B, Grellard JM, Babin E, Chauffert B, Dakpé S, Moldovan C, Bouhier-Leporrier K, Reimund JM, Di Fiore F, Zanetta S, Mailliez A, Do P, Peytier A, Galais MP, Florescu C, Schott R, Le Mauff B, Gervais R, Utility of serum anti-cetuximab immunoglobulin $\mathrm{E}$ levels to identify patients at a high risk of severe hypersensitivity reaction to cetuximab. $\mathrm{Br} J$ Clin Pharmacol., 2017; 83(3): 623-631.

15. Fiedler W, Cresta S, Schulze-Bergkamen H, De Dosso S, Weidmann J, Tessari A, Baumeister H, Danielczyk A, Dietrich B, Goletz S, Zurlo A, Salzberg M, Sessa C, Gianni L, Phase I study of tomuzotuximab, a glycoengineered therapeutic antibody against the epidermal growth factor receptor, in patients with advanced carcinomas. ESMO Open., 2018; 3(2):1-8.

16. Fischer J, Eberlein B, Hilger C, Eyer F, Eyerich S, Ollert M, Biedermann T, Alpha-gal is a possible target of IgE-mediated reactivity to antivenom. Allergy, 2017; 72(5): 764-771.

17. Fischer J, Yazdi AS, Biedermann T, Clinical spectrum of $\alpha$-Gal syndrome: from immediate-type to delayed immediate-type reactions to mammalian innards and meat. Allergo J Int., 2016; 25: 55-62.

18. Galili U, Discovery of the natural anti-Gal antibody and its past and future relevance to medicine. Xenotransplantation, 2013; 20(3): 138-147.

19. Hamad ML, Gupta A, Shah RB, Lyon RC, Sayeed VA, Khan MA, Functionality of magnesium stearate derived from bovine and vegetable sources: dry granulated tablets. J Pharm Sci., 2008; 97(12): 53285340.

20. Hamsten C, Starkhammar M, Tran TA, Johansson M, Bengtsson U, Ahlén G, Sällberg M, Grönlund H, van Hage $M$, Identification of galactose- $\alpha-1,3$-galactose in the gastrointestinal tract of the tick Ixodes ricinus; possible relationship with red meat allergy. Allergy, 2013; 68(4): 549-552.

21. Hamsten C, Tran TAT, Starkhammar M, Brauner A, Commins SP, Platts-Mills TAE, van Hage M, Red meat allergy in Sweden: association with tick sensitization and B-negative blood groups. J Allergy Clin Immunol., 2013; 132(6): 1431-1434.

22. Homann A, Schramm G, Jappe U, Glycans and glycan-specific $\operatorname{IgE}$ in clinical and molecular allergology: Sensitization, diagnostics, and clinical symptoms. J Allergy Clin Immunol., 2017; 140(2): 356-368.

23. Huai G, Qi P, Yang H, Wang Y, Characteristics of $\alpha$ Gal epitope, anti-Gal antibody, $\alpha 1,3$ galactosyltransferase and its clinical exploitation. Int $J \mathrm{Mol}$ Med., 2016; 37(1): 11-20.

24. Jappe U, Update on meat allergy. $\alpha$-Gal: a new epitope, a new entity? Hautarzt., 2012; 63(4): 299306.

25. Keating K, Walko C, Stephenson B, O'Neil BH, Weiss $\mathrm{J}$, Incidence of cetuximab-related infusion reactions in oncology patients treated at the University of North Carolina Cancer Hospital. J Oncol Pharm Pract., 2014; 20(6): 409-416. 
FARMACIA, 2019, Vol. 67, 1

26. Khoury JK, Khoury NC, Schaefer D, Chitnis A, Hassen GW, A tick-acquired red meat allergy: A case series. Am J Emerg Med., 2018, 36(2): 1-3.

27. Kleiman AM, Littlewood KE, Groves DS, Delayed anaphylaxis to mammalian meat following tick exposure and its impact on anesthetic management for cardiac surgery: A case report. A Case Rep., 2017; 8(7): 175-177.

28. Lammerts van Bueren JJ, Rispens T, Verploegen S, van der Palen-Merkus T, Stapel S, Workman LJ, James $\mathrm{H}$, van Berkel PH, van de Winkel JG, PlattsMills TA, Parren PW, Anti-galactose- $\alpha$-1,3-galactose IgE from allergic patients does not bind $\alpha$ galactosylated glycans on intact therapeutic antibody Fc domains. Nat Biotechnol., 2011; 29(7): 574-576.

29. Langerak A, River G, Mitchell E, Cheema P, Shing $\mathrm{M}$, Panitumumab monotherapy in patients with metastatic colorectal cancer and cetuximab infusion reactions: a series of four case reports. Clin Colorectal Cancer., 2009; 8(1): 49-54.

30. Li J, Fulton RB, O'Connell R, Jang HS, Fernando SL, Specific-IgE to galactose- $\alpha$-1,3-galactose (alpha-gal) has limited utility in diagnosing meat allergy in a tickendemic population. Ann Allergy Asthma Immunol., 2018; 121(4): 509-511.

31. Mariotte D, Dupont B, Gervais R, Galais MP, Laroche D, Tranchant A, Comby E, Bouhier-Leporrier K, Reimund JM, Le Mauff B, Anti-cetuximab IgE ELISA for identification of patients at a high risk of cetuximab-induced anaphylaxis. MAbs., 2011; 3(4): 396-401.

32. Mehlich J, Fischer J, Hilger C, Swiontek K, Morisset M, Codreanu-Morel F, Schiener M, Blank S, Ollert M, Darsow U, Biedermann T, Eberlein B, The basophil activation test differentiates between patients with alpha-gal syndrome and asymptomatic alpha-gal sensitization. J Allergy Clin Immunol., 2019; 143(1): 182-189.

33. Michel S, Scherer K, Heijnen IA, Bircher AJ, Skin prick test and basophil reactivity to cetuximab in patients with IgE to alpha-gal and allergy to red meat. Allergy, 2014; 69(3): 403-405.

34. Muglia C, Kar I, Gong M, Hermes-DeSantis ER, Monteleone C, Anaphylaxis to medications containing meat byproducts in an alpha-gal sensitized individual. J Allergy Clin Immunol Pract., 2015; 3(5): 796-797.

35. Mullins RJ, James H, Platts-Mills TA, Commins S, Relationship between red meat allergy and sensitization to gelatin and galactose- $\alpha-1,3$-galactose. J Allergy Clin Immunol., 2012; 129(5): 1334-1342.

36. Nasveld PE, Marjason J, Bennett S, Aaskov J, Elliott S, McCarthy K, Kanesa-Thasan N, Feroldi E, Reid M, Concomitant or sequential administration of live attenuated japanese encephalitis chimeric virus vaccine and yellow fever 17D vaccine: Randomized double-blind phase II evaluation of safety and immunogenicity. Human Vaccines, 2010; 6(11): 906914.

37. O'Neil BH, Allen R, Spigel DR, Stinchcombe TE, Moore DT, Berlin JD, Goldberg RM, High incidence of cetuximab-related infusion reactions in Tennessee and North Carolina and the association with atopic history. J Clin Oncol., 2007; 25(24): 3644-3648.
38. Platts-Mills TA, Schuyler AJ, Tripathi A, Commins SP, Anaphylaxis to the carbohydrate side chain alphagal. Immunol Allergy Clin North Am., 2015; 35(2): 247-260.

39. Popescu FD, Vieru M, Delayed anaphylaxis and urticaria to red meat in a patient from Southern Romania after multiple tick bites. Allergy, 2015; 70 (S101): 490.

40. Qian J, Liu T, Yang L, Daus A, Crowley R, Zhou Q, Structural characterization of N-linked oligosaccharides on monoclonal antibody cetuximab by the combination of orthogonal matrix-assisted laser desorption/ionization hybrid quadrupole-quadrupole time-of-flight tandem mass spectrometry and sequential enzymatic digestion. Anal Biochem., 2007; 364(1): 8-18.

41. Rauschenberg R, Beissert S, Bauer A, SpornraftRagaller P, Intraoperative anaphylactic reaction IV to gelatin. J Dtsch Dermatol Ges., 2014; 12(7): 617-618.

42. Rizer J, Brill K, Charlton N, King J, Acute hypersensitivity reaction to Crotalidae polyvalent immune $\mathrm{Fab}$ (CroFab) as initial presentation of galactose- $\alpha$-1,3-galactose ( $\alpha$-gal) allergy. Clin Toxicol (Phila), 2017; 55(7): 668-669.

43. Russell WJ, Fenwick DG, Anaphylaxis to Haemaccel and cross-reactivity to Gelofusin. Anaesth Intensive Care, 2002; 30(4): 481-483.

44. Saleh H, Embry S, Nauli A, Atyia S, Krishnaswamy $\mathrm{G}$, Anaphylactic reactions to oligosaccharides in red meat: a syndrome in evolution. Clin Mol Allergy, 2012; 10(1): 1-11.

45. Schiotis RE, Goșa D, Bocșan C, Suciu S, Buzoianu $\mathrm{AD}$, Particularities of treatment with conventional synthetic disease-modifying antirheumatic drugs (DMARDs) in a group of patients with rheumatoid arthritis. Farmacia, 2017; 65(3): 479-484.

46. Steinke JW, Platts-Mills TAE, Commins SP, The alpha-gal story: Lessons learned from connecting the dots. J Allergy Clin Immunol., 2015; 135(3): 589-596.

47. Stone CA Jr, Commins SP, Choudhary S, Vethody C, Heavrin JL, Wingerter J, Hemler JA, Babe K, Phillips EJ, Norton AE, Anaphylaxis after vaccination in a pediatric patient: further implicating alpha-gal allergy. J Allergy Clin Immunol Pract., 2019; 7(1): 322324.e2.

48. Stone CA Jr, Hemler JA, Commins SP, Schuyler AJ, Phillips EJ, Peebles RS Jr, Fahrenholz JM, Anaphylaxis after zoster vaccine: Implicating alphagal allergy as a possible mechanism. J Allergy Clin Immunol., 2017; 139(5): 1710-1713.

49. Swiontek K, Morisset M, Morel-Codreanu F, Mehlich J, Fischer J, Darsow U, Ollert M, Biedermann T, Eberlein B, Hilger C. Drugs of porcine origin - A risk for patients with alpha-gal syndrome? Clin Transl Allergy, 2018; 8(Suppl 1): 17.

50. Tjernberg I, Hamsten C, Apostolovic D, van Hage M, IgE reactivity to $\alpha$-Gal in relation to Lyme borreliosis. PLoS One, 2017; 12(9): 1-11.

51. Van Nunen SA, O'Connor KS, Clarke LR, Boyle RX, Fernando SL, An association between tick bite reactions and red meat allergy in humans. Med J Aust., 2009; 190(9): 510-511.

52. Venturini M, Lobera T, Sebastián A, Portillo A, Oteo $\mathrm{JA}, \mathrm{IgE}$ antibodies to alpha-gal in foresters and forest 
workers from La Rioja, North of Spain. J Investig Allergol Clin Immunol., 2018; 28(2): 106-112.

53. Vidal C, Méndez-Brea P, López-Freire S, GonzálezVidal T, Vaginal capsules: an unsuspected probable source of exposure to $\alpha$-Gal. $J$ Investig Allergol Clin Immunol., 2016; 26(6): 388-389.

54. Vieru M, Popescu FD, Secueanu A, Evidence of specific IgE to plant-derived cross-reactive carbohydrate determinant in a patient with delayed anaphylaxis to red meat. Clin Transl Allergy, 2016; 6(Suppl 2): 7-8.

55. Villalta D, Cecchi L, Farsi A, Chiarini F, Minale P, Voltolini S, Scala E, Quercia O, Muratore L, Pravettoni V, Calamari AM, Cortellini G, Asero R, Galactose- $\alpha$-1,3-galactose syndrome: an Italian survey. Eur Ann Allergy Clin Immunol., 2017; 49(6): 263-269.
56. Wen L, Zhou J, Yin J, Sun J, Sun Y, Wu K, Katial R. Delayed anaphylaxis to red meat associated with specific IgE antibodies to galactose. Allergy Asthma Immunol Res., 2015; 7(1): 92-94.

57. Wilson JM, Schuyler AJ, Schroeder N, Platts-Mills TA, Galactose- $\alpha$-1,3-galactose: atypical food allergen or model IgE hypersensitivity? Curr Allergy Asthma Rep., 2017; 17(1): 1-14.

58. Wilson JM, Platts-Mills TAE, IgE to galactose- $\alpha-1,3-$ galactose and the $\alpha$-Gal syndrome: Insights from Basophil Activation Testing. J Allergy Clin Immunol., 2019; 143(1): 101-103.

59. Yokoi H, Yoshitake H, Matsumoto Y, Kawada M, Takato Y, Shinagawa K, Sakurai H, Saito K, Involvement of cross-reactive carbohydrate determinants-specific $\operatorname{IgE}$ in pollen allergy testing. Asia Pac Allergy, 2017; 7(1): 29-36.

60. www.ema.europa.eu 